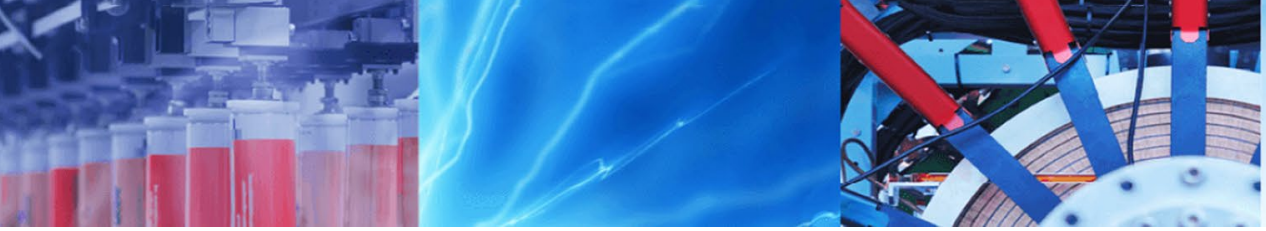

Research Article

\title{
Comparative evaluation of biodiesel production and engine characteristics of Jatropha and Argemone Mexicana oils
}

\author{
Asfafaw Haileselassie Tesfay ${ }^{1,2}$ D . Solomon Hailu Asfaw ${ }^{2} \cdot$ Michael Gebreyesus Bidir $^{2}$
}

(c) Springer Nature Switzerland AG 2019

\begin{abstract}
This paper deals with a performance evaluation of locally made $20 \mathrm{~L}$ batch type reactor and JP and AM biodiesels produced by using this reactor. The inputs for transesterification process were Jatropha and Argemone Mexicana oils, with an alcohol to oil molar ratio of $6: 1,1 \% \mathrm{NaOH}$ catalyst, $55^{\circ} \mathrm{C}$ reaction temperature, an hour settling time and $600 \mathrm{rpm}$ agitation speed. The conversion ability of the reactor for Jatropha and Argemone Mexicana oil seeds has shown a 94\% and $94.5 \%$, respectively. The property of these biodiesels has analyzed and its result was within the limit of ASTM D6751. Performance and emission behavior of different blends of these oils such as B10, B20, B30 and pure diesel were evaluated in a single cylinder, four stroke $\mathrm{Cl}$ engine with rated speed of $1500 \mathrm{rpm}$ and rated power of $4 \mathrm{~kW}$. The $\mathrm{B} 10$ blend has shown closer characteristics in terms of specific fuel consumption, brake thermal efficiency and exhaust gas temperature at different loads to diesel. On the other hand, $\mathrm{B} 10$ has resulted with higher $\mathrm{CO}_{2}$ and $\mathrm{CO}$ and lower $\mathrm{NOx}$ emission potential compared to the two blends. The lower $\mathrm{NO}_{2}$ emission is due to its lowest exhaust gas temperature. The biodiesels finally pass standard tests of EPE by fulfilling the standard parameters that made them competitive and substitute options to diesel fuel.
\end{abstract}

Keywords Biodiesel reactor · Jatropha $\cdot$ Argemone Mexicana $\cdot$ Biofuel emission · Biofuel engine characteristics

\section{Introduction}

In recent years, the transportation sector has considered as higher greenhouse gas emitter. The investment for fuel in the sector has also become very expensive and non-symbioses [1]. Consequently, bio-energy become as a solution to reduce the GHG emission of the sector and insure sustainable supply of fuel to non-petroleum producing countries like Ethiopia to sustain their economic development [2]. Generally, biodiesel production is costly especially biodiesel from edible oil seeds is not price competitive with fossil fuel [3]. However, non-edible oil seeds become promising crude oils to produce biodiesel [4]. Biodiesel has attracted considerable attention because of its renewable, biodegradable and non-toxic nature [5]. However, as a potential fuel its production cost has to compete with fossil fuel. One way of reducing the production costs of biodiesel is to use abundant and nonedible feedstock that contain low free fatty acids (FFA) with easy production process. In this regard, the availability and sustainable supply of such feedstock determines the competitive potential of biodiesel. Food versus fuel controversy indicates that edible oil seeds are not an ideal feedstock for biodiesel production. The use of non-edible oil seeds as alternative feedstock is picking up as the demand for biodiesel increases. Jatropha and Argemone Mexicana are potential feedstocks due to their fast growth and availability [6]. Studies of biodiesel from Argemone Mexicana oil seed has shown a $90 \%$ yield with about $3 \%$ FFA in a single step sodium methoxide $\left(\mathrm{CH}_{3} \mathrm{ONa}\right)$ catalyzed transesterification

$\triangle$ Asfafaw Haileselassie Tesfay, asfafaw.haileslassie@mu.edu.et | ${ }^{1}$ Institute of Energy Mekelle University, P.O. Box 231, Mekelle, Tigray, Ethiopia. ${ }^{2}$ School of Mechanical and Industrial Engineering, Ethiopian-Institute of Technology-Mekelle, Mekelle University, P.O. Box 231, Mekelle, Tigray, Ethiopia.

SN Applied Sciences (2019) 1:1075 | https://doi.org/10.1007/s42452-019-1075-2

Received: 28 January 2019 / Accepted: 10 August 2019 / Published online: 23 August 2019 
process $[7,8]$. However, sodium methoxide is corrosive. On the other hand, crystalline manganese a non-corrosive, versatile and low cost catalyst has shown similar conversion of oil to fatty acid methyl ester (FAME) [7]. Dorado et al. research on biodiesel refining of edible oil using methanol and alkaline catalyst show sensitiveness to FFA and water. In addition, the production process consumes the catalyst and thereby reduce the yield of biodiesel [9]. Chemically, biodiesel has defined as the mono-alkyl ester of the long chain family fatty acid derived from renewable bio lipids. It mainly produced through the transesterification process of vegetable oils or animal fats with methanol or ethanol by the help of a catalyst. The product is methyl or ethyl ester and a byproduct of glycerin.

William et al. study show the acceptable amount of FFA and water is $0.5 \%$ and $0.3 \%$ respectively [10]. The most common way to produce biodiesel in all scale is transesterification. It can be either alkali, acid or enzymatic catalyzed process [11]. Many researchers' suggest base catalyzed biodiesel conversion for lab scale in order to get maximum conversion of fatty acid methyl ester. Optimum reaction would obtained at reaction temperature of below boiling point of alcohol; oil to alcohol molar ratio of 6:1 and $1.0 \%$ by weight $\mathrm{NaOH}$ [12]. Accordingly, regardless of their quantity and quality the production process of small scale and laboratory scale biodiesel is similar with proportional input ratios [8]. In order to achieve the ASTM standard, the equipment used to produce biodiesel should fulfill the quality standard. Most small-scale biodiesel reactors are easy to manufacture and handle; however, they required serous material selection. The transesterification process in a batch type biodiesel reactor would carried out by pouring non-edible vegetable oil with correct amount of methanol and sodium hydroxide catalyst. An excess amount of methanol helps to accelerate the solubility and triglyceride process and keep the mixture viscosity low. However, in return it shifts the chemical reaction equilibrium of methyl ester. Similarly, excess sodium hydroxide leads to saponification [13].

Daniyam et al. [14] have examined vegetable and used cooking oil as production inputs of biodiesel on a $20 \mathrm{~L}$ batch type biodiesel reactor. Their evaluation has performed by heating the vegetable oil up to $100^{\circ} \mathrm{C}$ to remove its water content and cooled it to $60^{\circ} \mathrm{C}$. The process has run for $3 \mathrm{~h}$ with molar ratio of oil to methanol $6: 1$, reaction temperature of $60^{\circ} \mathrm{C}$ and agitation speed of $200 \mathrm{rpm}$. Similarly, the used cooking oil has heated to $120^{\circ} \mathrm{C}$ to reduce the impurities and FFA content before further process. The heating process continues until the FFA falls below $1-0.5 \%$ and the transesterification lies within the specification of biodiesel. In batch type reactor, the oil and mixture of alcohol and catalyst would heated to a preset temperature. This process is known for its flexibility of accepting different feedstocks but it has higher operating cost [15]. Continuous reaction process is a new concept in biodiesel production process. The working principle is to be continuous with a very low pressure to accept feedstocks with higher FFA contents. Such process requires two reactors connected in series for esterification and transesterification process. Consequently, the produced biodiesel does not need further treatment.

Extracted biodiesel fuels has to go for engine performance test prior to their mass production. Accordingly, many researches have conducted in this area of intervention. Hanumantha Rao et al. have analyzed Jatropha biodiesel blends in a four-stroke direct injection and water-cooled diesel engine with $3.6 \mathrm{~kW}$ rated power and $1500 \mathrm{rpm}$ maximum speed [16]. A blended fuel B25, B50, $B 75$ and $B 100$ were used. The researchers used a mixture of $10 \mathrm{~g} \mathrm{NaOH}$ as catalyst and $450 \mathrm{ml}$ of methanol added to a $1000 \mathrm{ml}$ Jatropha crude oil to produce biodiesel. The methyl ester of Jatropha oil has washed and dried in order to smooth the operation in diesel engine to analyze its properties such as flash point, kinematic viscosity, specific gravity and carbon residue to meet the ASTM 6751-02 standards of biodiesel and keep its calorific value within the limit. Similarly, Elango et al. have investigated the performance, and emission characteristics of non-edible vegetable oil, and diesel blends B10 to B50 on single cylinder $\mathrm{Cl}$ engine coupled with hydraulic dynamometer [17]. The investigation has focused on specific fuel consumption, brake thermal efficiency, exhaust gas temperature and $\mathrm{CO}_{2}$ emission. The result has shown that specific fuel consumption decreased with varying applied load of $0-3.9 \mathrm{~kW}$ and it achieved brake thermal efficiency of 0-29.39\%. A similar research by Sherwani et al. has conducted on mahua oil ethyl ester B5, B10, B15 and B20 blends by using four stroke single cylinder direct injection, water cooled and rope brake actuated dynamometer $\mathrm{Cl}$ engine. Generally, the results have shown a decrease on specific fuel consumption with increased load. At no load conditions, all the blends and diesel fuel have the same brake thermal efficiency. However, with applied load the brake thermal efficiency of B10 has found better than diesel. In addition, the brake thermal efficiency of B15 and B20 is similar to conventional diesel fuel. On the other hand, B5 blend has shown increased $\mathrm{CO}_{2}$ emission but still lower than diesel fuel. The quality of biodiesel is very important in-order to determine its performance and emission characteristics on $\mathrm{Cl}$ engine. Standardizing biodiesel would increase its acceptance by engine manufacturers. ASTM D6751 is one of the most common standards set for B100 biodiesel fuel [18]. The most important properties of biodiesel and fossil fuels have shown in Table 1. The value of density has not given by ASTM D6751 but the European standard EN14214 gives between $0.86 \mathrm{~g} / \mathrm{cm}^{3}$ and $0.9 \mathrm{~g} / \mathrm{cm}^{3}$ as shown in 
Table 1 Properties of biodiesel and fossil diesel (ASTM D6751 and D975) [18]

\begin{tabular}{llll}
\hline Fuel property & Biodiesel & Diesel & Units \\
\hline Fuel standard & ASTM D6751 & ASTM D975 & \\
Kinematic viscosity @ $40{ }^{\circ} \mathrm{C}$ & $1.9-6.0$ & $1.3-4.1$ & $\mathrm{~mm}^{2} / \mathrm{s}$ \\
Specific gravity @ $60{ }^{\circ} \mathrm{C}$ & 0.88 & 0.85 & $\mathrm{~kg} / \mathrm{l}$ \\
Density [EN14214] & $0.86-0.9$ & 0.85 & $\mathrm{gm} / \mathrm{cm}^{2}$ \\
Water and sediment & $0.05 \mathrm{max}$ & $0.05 \mathrm{max}$ & $\%$ volume \\
Carbon & 77 & 87 & $\mathrm{wt} \%$ \\
Flash point & $130-170$ & $60-80$ & ${ }^{\circ} \mathrm{C}$ \\
Cloud point & -3 to 12 & -15 to 5 & ${ }^{\circ} \mathrm{C}$ \\
Pour point & -15 to 10 & -35 to -15 & ${ }^{\circ} \mathrm{C}$ \\
Heating value & $34.4-45$ & $42-45$ & $\mathrm{MJ} / \mathrm{kg}$ \\
\hline
\end{tabular}

Table-1. However, fossil diesel has got $0.85 \mathrm{~g} / \mathrm{cm}^{3}$ that is lower than biodiesel.

Ethiopia relies on imported petroleum for its transportation, which took the lion share of its budget and foreign currency demand as shown in Fig. 1 [19]. Consequently, the government gives priority to fuel substitution to satisfy its fuel demand. Subsequently, there are many investors involved in the production of energy crops such as Jatropha and castor bean. Jatropha is a globally accepted oil seed for its multipurpose and drought resistance nature. It can grow in a grey lands and it can give production for about 50 years. The oil content of Jatropha is $34 \%$ by weight in which extracted oil does not need further refining and its residue could be used as animal feed and fertilizer [20].

This research has based on a locally developed $20 \mathrm{~L}$ batch type biodiesel reactor that has registered $94.5 \%$ conversion efficiency of Jatropha oil. This conversion has attained on the bases of $20 \%$ ethanol, $1 \%$ sodium hydroxide, $55^{\circ} \mathrm{C}$ reaction temperature, $600 \mathrm{rpm}$ agitation speed and $1 \mathrm{~h}$ settling time. However, the biodiesel was found to have a large percentage of impurities. In addition, its test in accordance to ASTM standards has resulted a shelf life of less than 2 months. The results presented in this research is a follow up of this work with the following objectives:

1. Evaluate the reactor performance on Jatropha oil and Argemone Mexicana oil

2. Study the effect of catalyst concentration, methanol to oil molar ratio, reaction time, agitation speed and temperature
Fig. 1 Trends of Ethiopia's oil import and cost a trends of volume of petroleum imports and $\mathbf{b}$ costs of petroleum imports [19]

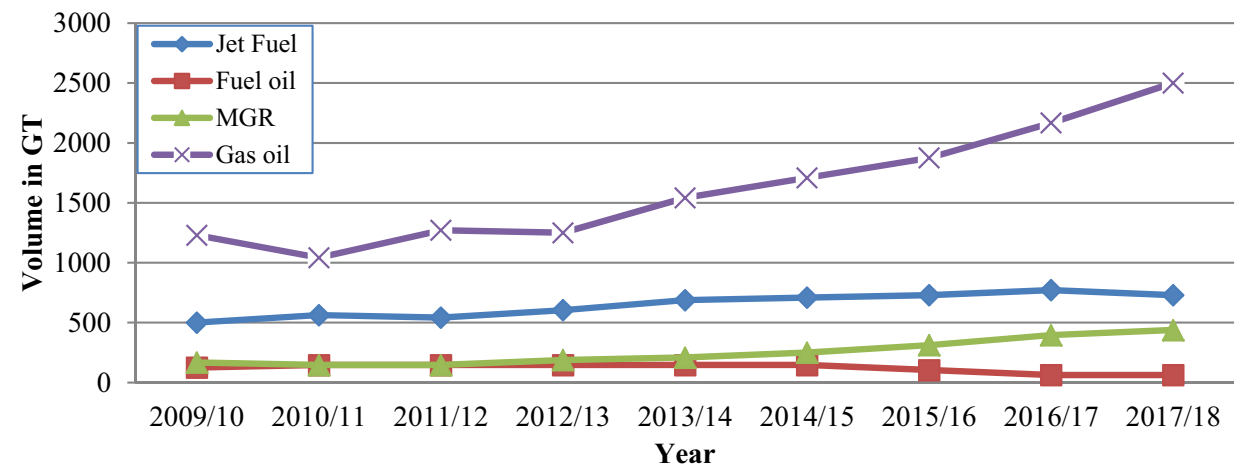

(a)

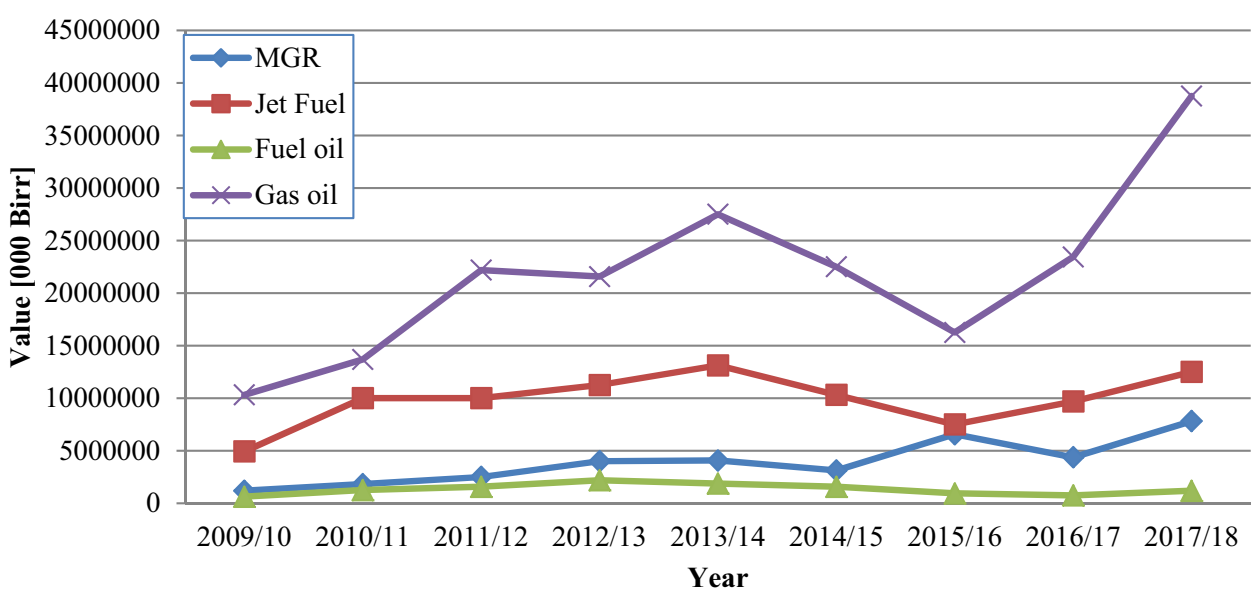

(b) 
3. Study physicochemical property of the produced biodiesel in accordance to ASTM D6751

4. Study the engine performance of Jatropha and Argemone Mexicana in IC engine.

\section{Materials and methods}

In this research, different materials and equipment have been used to conduct the study. These include purified biodiesel oil of Jatropha and AM, Methanol with 99.7\% concentration, Sodium Hydroxide with $99.9 \%$ concentration and distilled water. Some apparatuses such as digital scale, $5 \mathrm{~L}$ flask, burette, thermometer, stopwatch, $20 \mathrm{~L}$ reactor, oven, screw oil extractor, magnetic stirrer, IC engine, exhaust gas analyzer and thermocouples have used to measure different physicochemical properties.

This research has conducted by employing the following three methodologies

Table 2 Experimental setup of factors affecting yield of biodiesel

\begin{tabular}{llllll}
\hline $\begin{array}{l}\text { Expt. no. } \\
\begin{array}{l}\text { Tem- } \\
\text { perature } \\
\left({ }^{\circ} \mathrm{C}\right)\end{array}\end{array}$ & MR (\%) & $\begin{array}{l}\text { Time } \\
(\mathrm{min})\end{array}$ & $\begin{array}{l}\text { Catalyst } \\
(\%)\end{array}$ & $\begin{array}{l}\text { Agitation } \\
\text { speed (rpm) }\end{array}$ \\
\hline 1 & 40 & $4: 1$ & 30 & 0.5 & 400 \\
2 & 50 & $6: 1$ & 60 & 0.75 & 500 \\
3 & 55 & $7: 1$ & 90 & 1 & 600 \\
4 & 60 & $8: 1$ & 120 & 1.25 & 700 \\
\hline
\end{tabular}

\subsection{Extraction of biodiesel}

The experimental design to investigate the methyl ester yield has focused on five selected factors, methanol to oil molar ratio, catalyst concentration, reaction temperature, agitation speed and reaction time. Twenty experiments with four levels as given in Table 2 have conducted. The different physicochemical properties of Jatropha and Argemone Mexicana biodiesel have finally examined in the laboratory of Ethiopian Petroleum Supply Enterprise (EPE) for verification.

The seeds of Jatropha and Argemone Mexicana have shown in Fig. 2a, b have collected from northern Wollo of Amhara region and Hagereselam of Tigray region Ethiopia, respectively. The Jatropha seeds have dried in an oven at a temperature of $40-50^{\circ} \mathrm{C}$ for $2 \mathrm{~h}$ to have easy separation of the Jatropha kernel from the seed coat. The oil extraction has done by single screw mechanical extractor. This extraction method avoids pretreatment costs like dehaulling, drying, cooking and faking. The extracted oil of AM and Jatropha have presented in Fig. $3 a$, b respectively. The transesterification process has done by using a $20 \mathrm{~L}$ batch type reactor with different methanol to oil molar ratio, agitation speed, temperature and settling time.

The biodiesel, from the two purified crude oils and methanol with a homogenous catalyst basic sodium hydroxide, transesterification process has shown in Fig. 4.
Fig. 2 Oil seeds of a Jatropha and $\mathbf{b}$ Argemone Mexicana

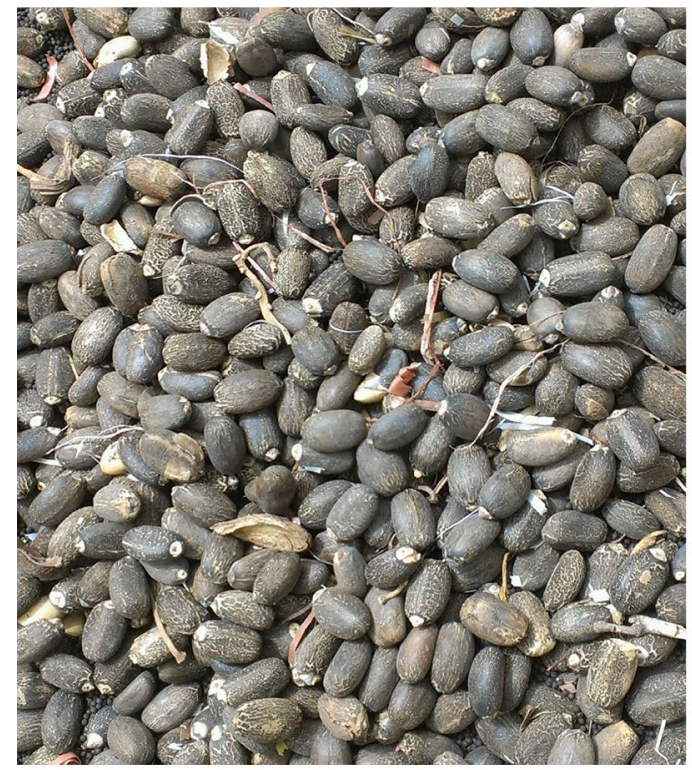

(a)

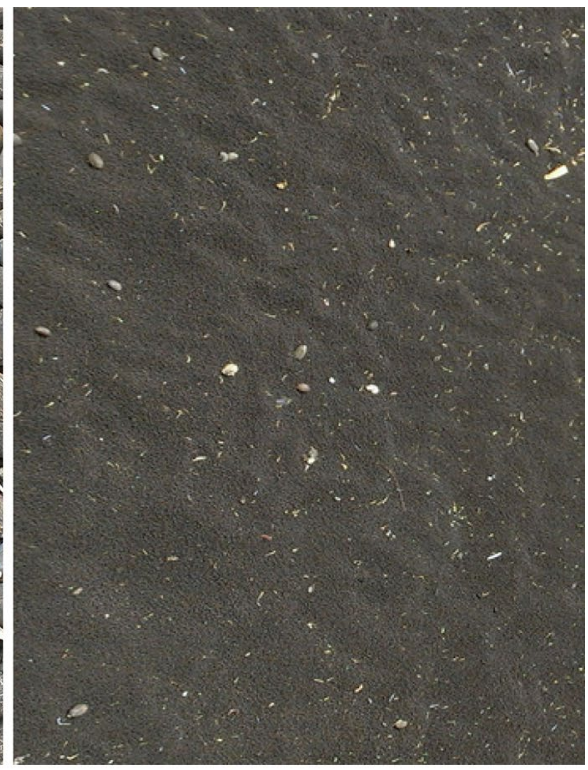

(b) 


\subsection{Performance evaluation of a 20L batch type reactor}

The performance evaluation of the reactor was conducted by running six experiments on a fixed design parameter of the reactor, which are temperature $55^{\circ} \mathrm{C}$, 6:1 molar ratio, $1 \%$ catalyst, settling time of $1 \mathrm{~h}$ and $600-$ rpm agitation speed as presented in Table 3.

Figure 5 shows the biodiesel extraction process and actual test rig of the biodiesel reactor. The arrangement combines a reactor vessel of $20 \mathrm{~L}$, mechanical stirrer, variable speed electrical motor; thermocouple actuated electrical heater and manually controlled discharge valve.

Fig. 3 Extracted oils. a Argemone Mexicana oil and $\mathbf{b}$ Jatropha oil

\subsection{Engine performance test}

The extracted biodiesels have tested in $\mathrm{Cl}$ engine by focusing on studies of fuel specific consumption, brake thermal efficiency, exhaust gas temperature and emission with respect to brake power. The engine used in this investigation was a single cylinder, four stroke, air-cooled $\mathrm{Cl}$ engine coupled to rope actuated dynamometer. The schematic drawing and actual test rig has shown in Fig. 6. The fuel-engine performance test has carried out by using computerized tune up center 2005 m, KAL EQUIP emission analyzer 5000 to analyze the contents of $\mathrm{CO}_{2}, \mathrm{CO}$ and $\mathrm{NOx}$ for different blends and brake thermal loads. The engine technical specification has tabulated in Table 4.

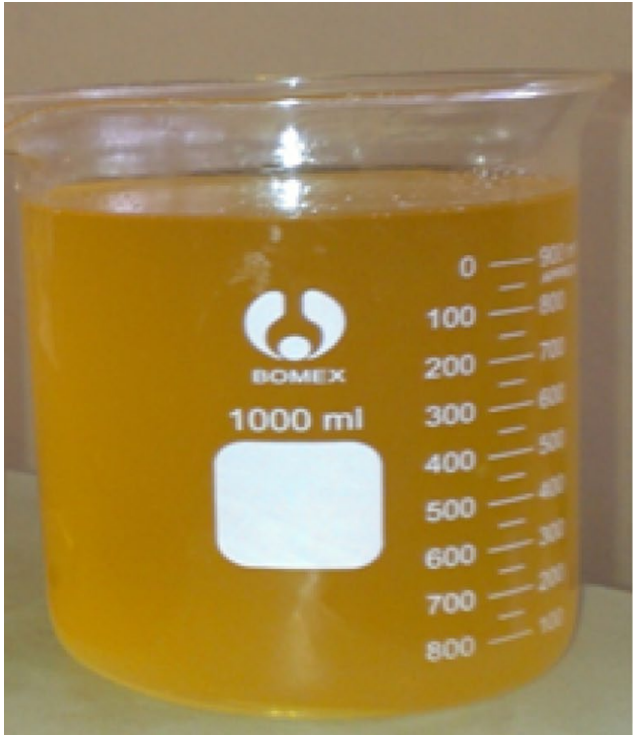

(a)

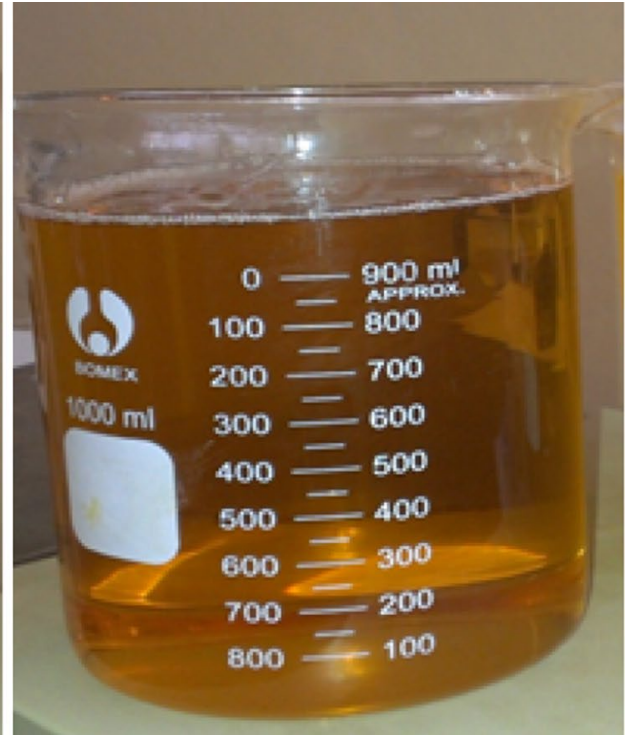

(b)
Fig. 4 Stoichiometry of Transesterification

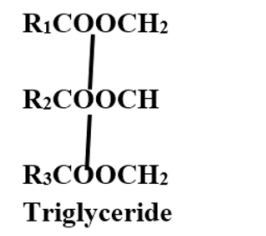

Triglyceride

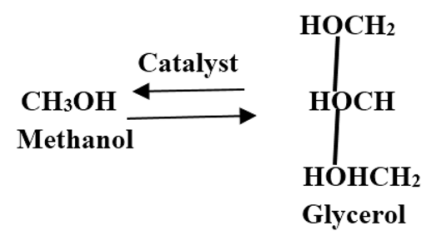

$\mathrm{R}_{1} \mathrm{COOCH}_{3}$

$\mathrm{R}_{2} \mathrm{COOCH}_{3}$

$\mathrm{R}_{2} \mathrm{COOCH}_{3}$

Methyl ester (biodiesel)
Table 3 Performance evaluation of biodiesel reactor

\begin{tabular}{llllllll}
\hline Expt. & Tem. ${ }^{\circ} \mathrm{C}$ & MR (\%) & Time (M) & $\begin{array}{l}\text { Catalyst } \\
\text { Con. }(\%)\end{array}$ & Agitation (rpm) & \multicolumn{2}{l}{$\begin{array}{l}\text { Yield of FAME } \\
{[\%]}\end{array}$} \\
\cline { 3 - 7 } & & & & & JC & AM \\
\hline 1 & 55 & $6: 1$ & 60 & 1 & 600 & 93.5 & 94.5 \\
2 & 55 & $6: 1$ & 60 & 1 & 600 & 96 & 92 \\
3 & 55 & $6: 1$ & 60 & 1 & 600 & 96.3 & 92.5 \\
4 & 55 & $6: 1$ & 60 & 1 & 600 & 94.2 & 96 \\
5 & 55 & $6: 1$ & 60 & 1 & 600 & 95 & 95 \\
6 & 55 & $6: 1$ & 60 & 1 & 600 & 92.5 & 94 \\
\hline
\end{tabular}


Fig. 5 A 20 L batch type biodiesel reactor. a Biodiesel extraction process and $\mathbf{b}$ actual reactor test rig

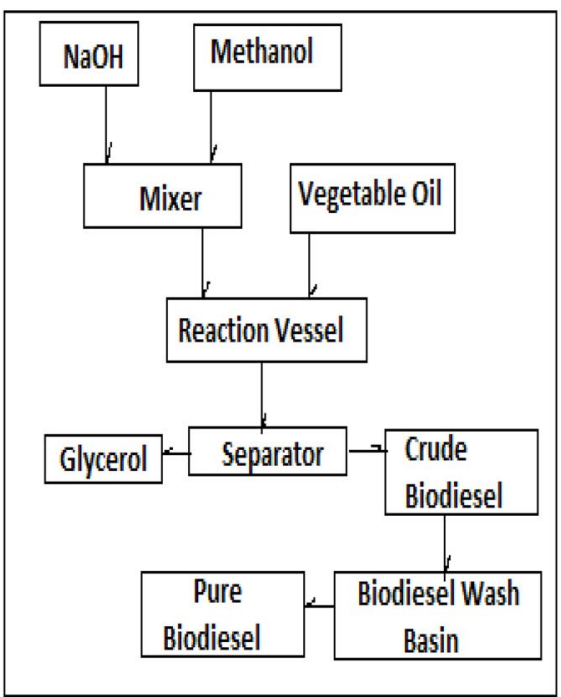

(a)

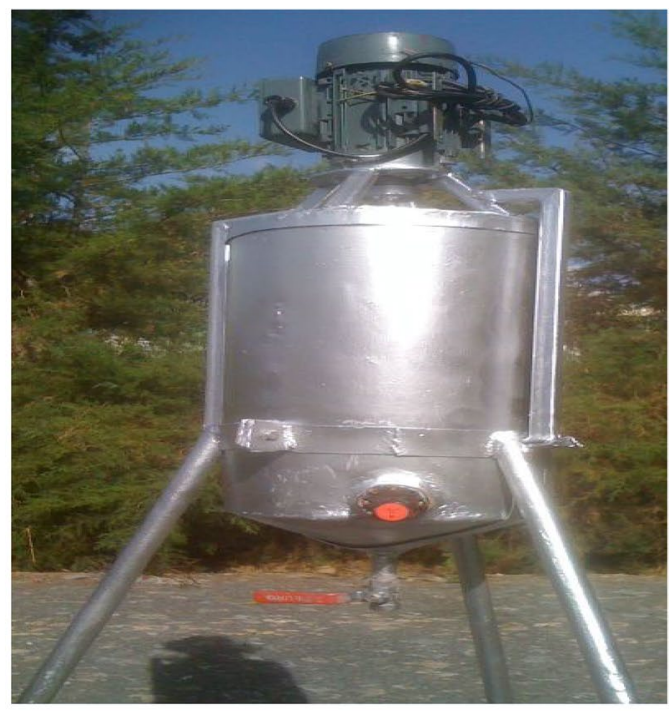

(b)

Fig. 6 Engine performance test of biodiesel. a Schematic and $\mathbf{b}$ actual test rig

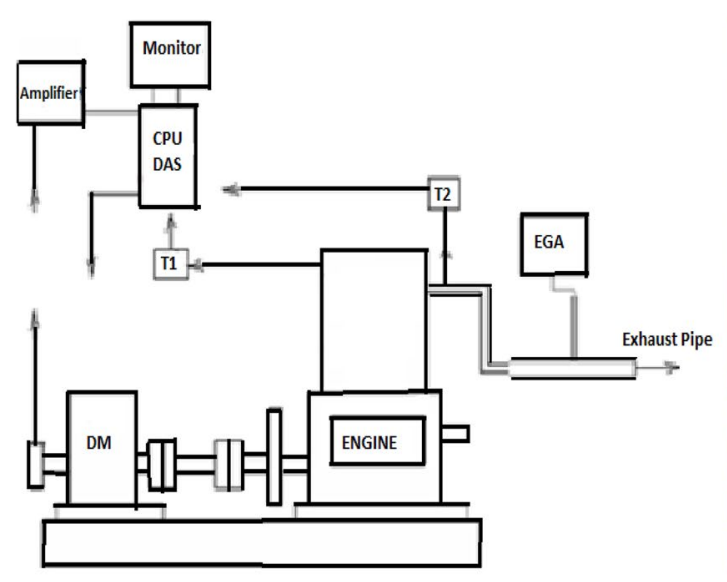

(a)

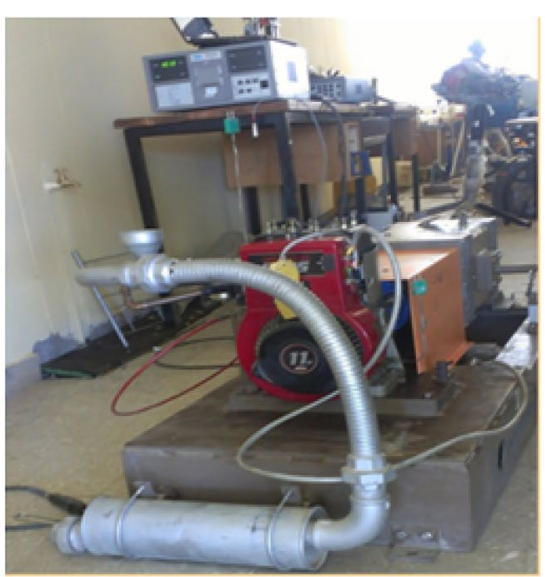

(b)
Table 4 Engine specification

\begin{tabular}{ll}
\hline Characteristics & Value \\
\hline Engine type & $\begin{array}{c}\text { Four stroke, single cylinder, } \\
\text { air cooled, Cl diesel } \\
\text { engine }\end{array}$ \\
Rated speed & $1500 \mathrm{rpm}$ \\
Stroke & $87.5 \mathrm{~mm}$ \\
Bore & $110 \mathrm{~mm}$ \\
Compression ratio & $17.5: 1$ \\
Brake power & $4 \mathrm{kw}$ \\
\hline
\end{tabular}

\section{Results and discussion}

The reactor gave an average yield of $94 \%$ biodiesel from both oils. The engine specific fuel consumption for different blends of biodiesel and conventional diesel in a $\mathrm{Cl}$ engine has shown in Fig. 7. The result shows no significant difference on the specific fuel consumption of B10 and B20 of Jatropha and Argemone Mexicana with that of conventional diesel fuel. In addition, the specific fuel consumption of the different blends during start up was high and decreased with increased brake power and becomes near constant at higher brake power. Moreover, the specific fuel consumption decreases with increasing blend due to increased viscosity of the fuel, which creates a poor atomization in the engine injection system. 
Fig. 7 Variation of SFC with BP. a Jatropha and $\mathbf{b}$ Argemone Mexicana

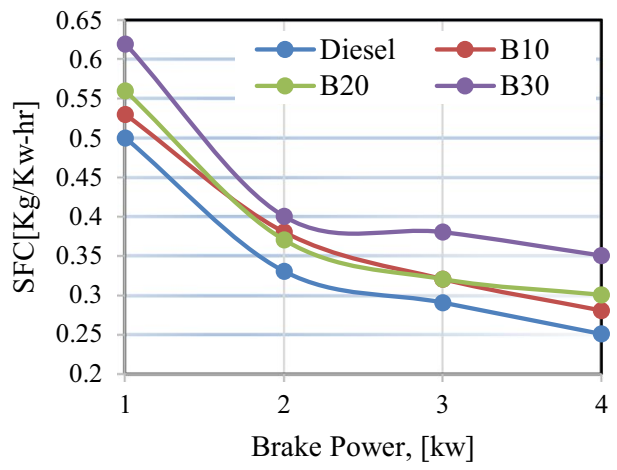

(a)

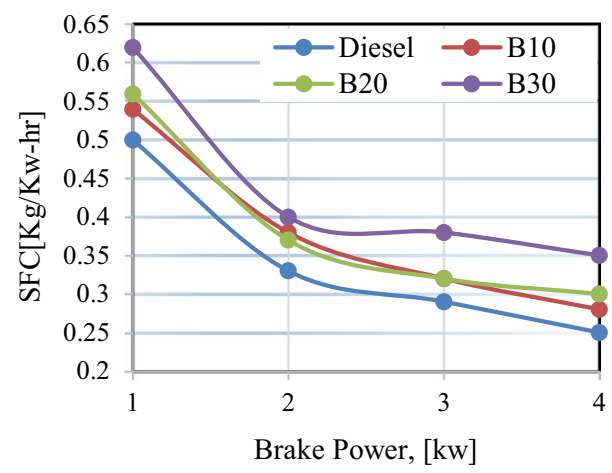

(b)
In addition, $\mathrm{B} 10$ and $\mathrm{B} 20$ of both fuels have nearest value of specific fuel consumption to diesel that shows B10 and $\mathrm{B} 20$ have the potential to replace diesel fuel.

The brake thermal efficiency (BTE) has observed to decrease with an increase of blend compared to diesel. Figure 8 shows the brake thermal efficiency of B10 of both biodiesels has reached $29 \%$ at brake power of $3.8 \mathrm{~kW}$. In addition, it revels B10 and B20 have near and the same BTE at same break power. On the other hand, the BTE of the biodiesels has observed to raise with blends, however, as the thermal efficiency of an engine is dependent on the heating value of the fuel. Jatropha and Argemone Mexicana oil fuels have registered $12 \%$ and $11 \%$ less heating value than conventional diesel fuel respectively. It has also observed that B10 and B20 have shown no significant difference in their brake thermal efficiencies. Moreover, the brake thermal efficiency of Argemone Mexicana is a bit different from Jatropha blend due to the slight difference in heating value. Generally, the declination of BTE with increased blend is due to poor atomization of the fuel in the engine combustion chamber.

Exhaust gas temperature has used as one criteria for performance evaluation of a diesel engine run by different blends of biodiesel and diesel fuel. This study has also used this method of evaluation and the results have indicated that increased break power. In addition, the lower blends develop lower temperature as shown in Fig. 9. This is because of the excess oxygen found in biodiesel fuel has a chance to complete the combustion process and increases the exhaust gas temperature. Moreover, the overall exhaust gas temperature has also affected by the engine cooling system efficiency.

Series of experiments on the different blends of the biodiesels and diesel fuel have conducted to evaluate engine emission levels for $\mathrm{CO}_{2}, \mathrm{CO}$ and NOx. Figure 10 shows the variation of $\mathrm{CO}_{2}$ emission with brake power. The figure reveals that the level of $\mathrm{CO}_{2}$ emission increases with applied load in all blends and diesel. The maximum

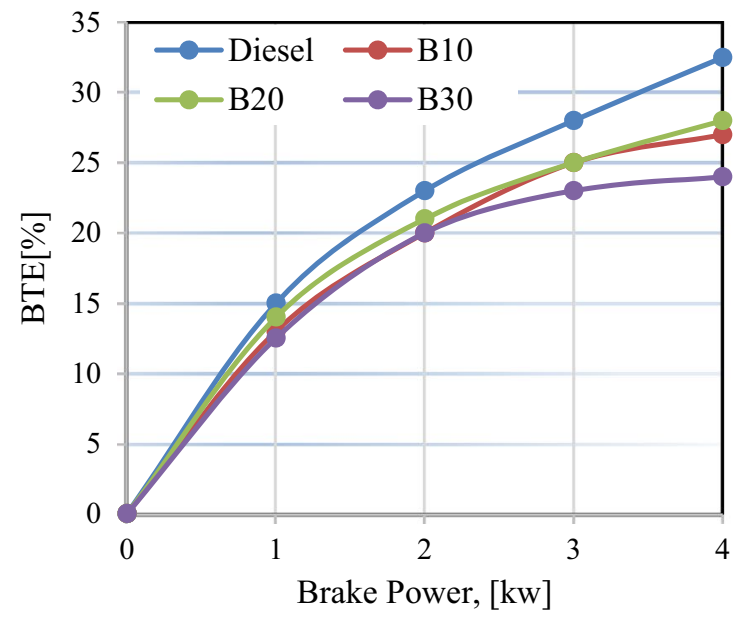

(a)

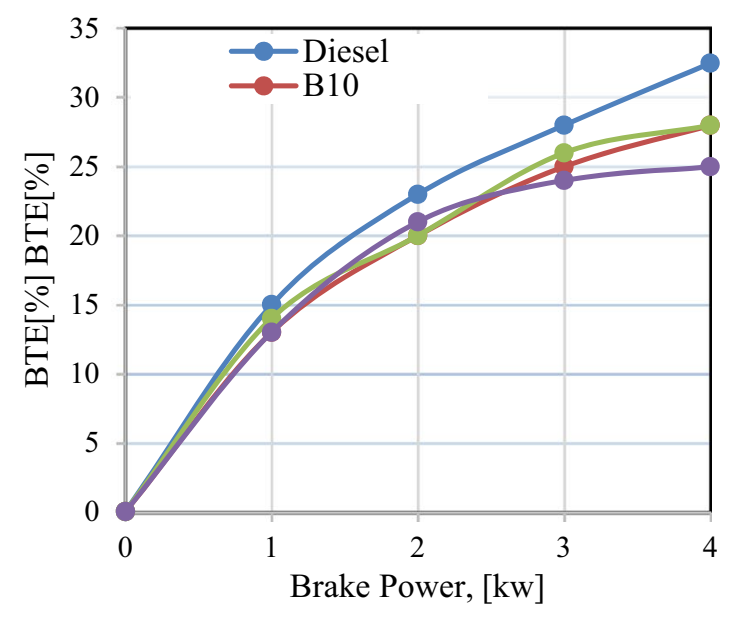

(b)

Fig. 8 Variation of Brake thermal efficiency with brake power. $\mathbf{a}$ Jatropha and $\mathbf{b}$ Argemone Mexicana 


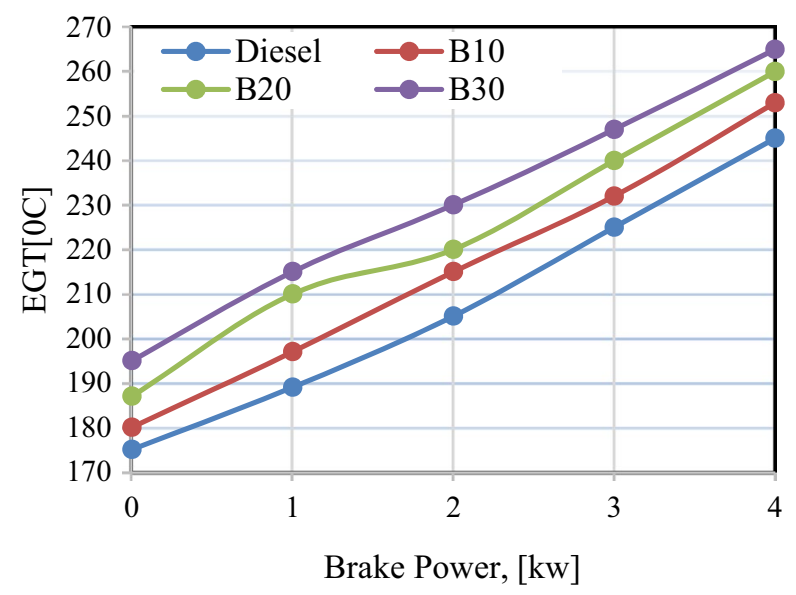

(a)

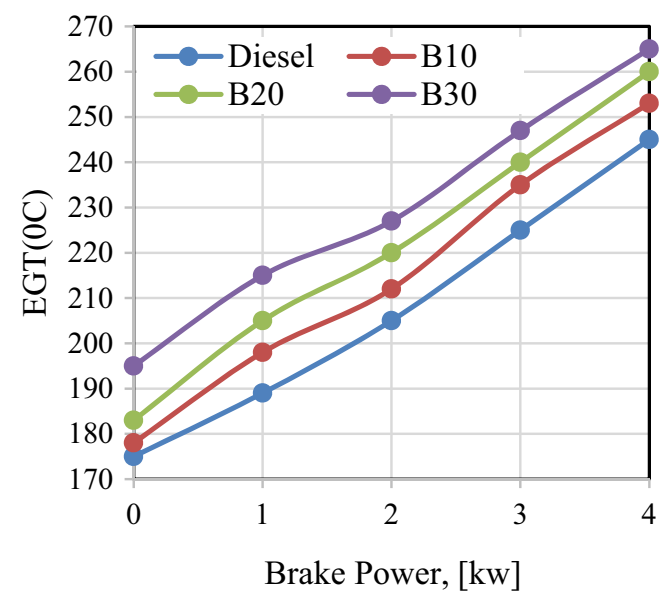

(b)

Fig. 9 variation of brake thermal with brake thermal. a Jatropha and $\mathbf{b}$ Argemone Mexicana

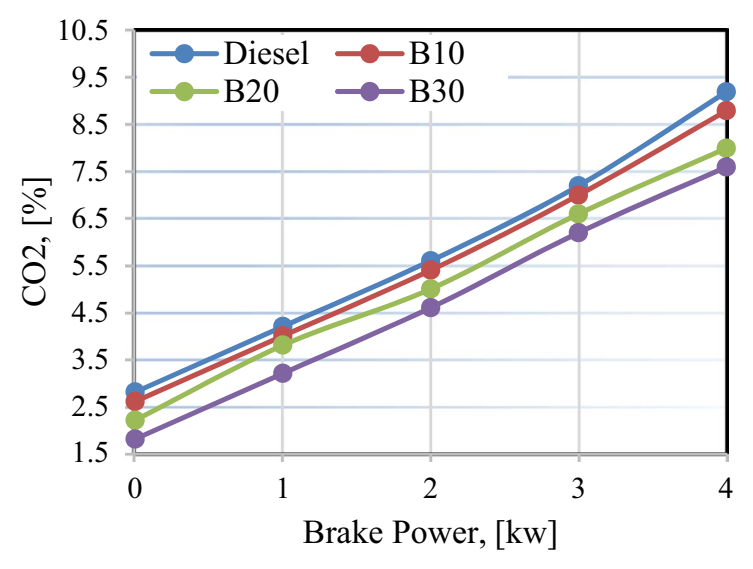

(a)

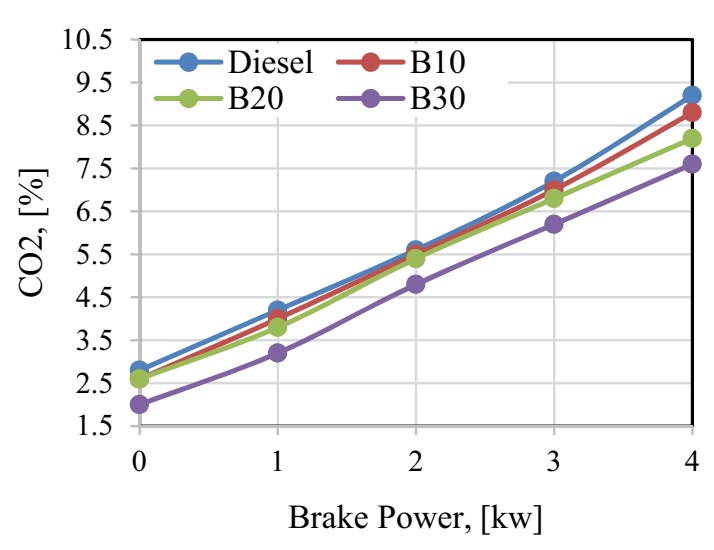

(b)

Fig. 10 Variation of $\mathrm{CO}_{2}$ with brake power. a Jatropha and $\mathbf{b}$ Argemone Mexicana

applied gives maximum $\mathrm{CO}_{2}$ emission this is also true as the fuel blend increases. Diesel fuel is the highest contributor of un-burnt $\mathrm{CO}_{2}$ gas relative to the three blends. This shows biodiesel blend has better combustion. However, among the biodiesel blends, higher blend shows less $\mathrm{CO}_{2}$ emission due to lower content of carbon.

Figure 11 shows the variation of $\mathrm{CO}$ with applied brake power. It has observed that there was a gradual decrease of $\mathrm{CO}$ emission for biodiesel blends. The blends show a continuous decrease until a brake power of $3 \mathrm{~kW}$ and increase again but B10 and B20 remained at $0.02 \%$. However, B30 continues to give lower emission even at higher brake power. Biodiesel has in general higher content of oxygen, which helps to release a lesser $\mathrm{CO}$ and $\mathrm{CO}_{2}$ to the atmosphere compared to conventional fuel. Similarly, Fig. 12 shows the emission level of NOx with brake power of the different blends of biodiesel and diesel. NOx is formed by the reaction of atmospheric nitrogen and oxygen at a very high temperature. Therefore, at higher load the temperature of the cylinder goes to peak. This also increases with higher blends because of the late ignition of the injected fuels. In general, biodiesel has higher formation tendency of NOx compared to fossil diesel.

Transesterification process is the conversion of fatty acid ester to Methyl/ethyl ester by using alcohol and catalyst. The byproducts are glycerol and FAME it can also a reversible process. This is also a process of reducing the high viscosity property of animal fats and plant oils in order to use them as alternative energy source. Factors that affect the yield of transesterification processes are reaction time, alcohol to oil molar ratio, type and concentration of catalyst, reaction temperature and mixing intensity [21]. 


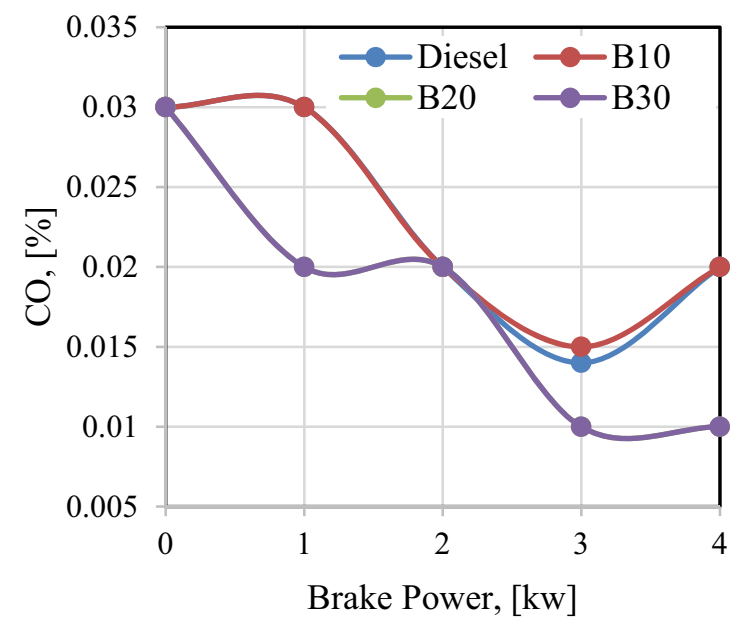

(a)

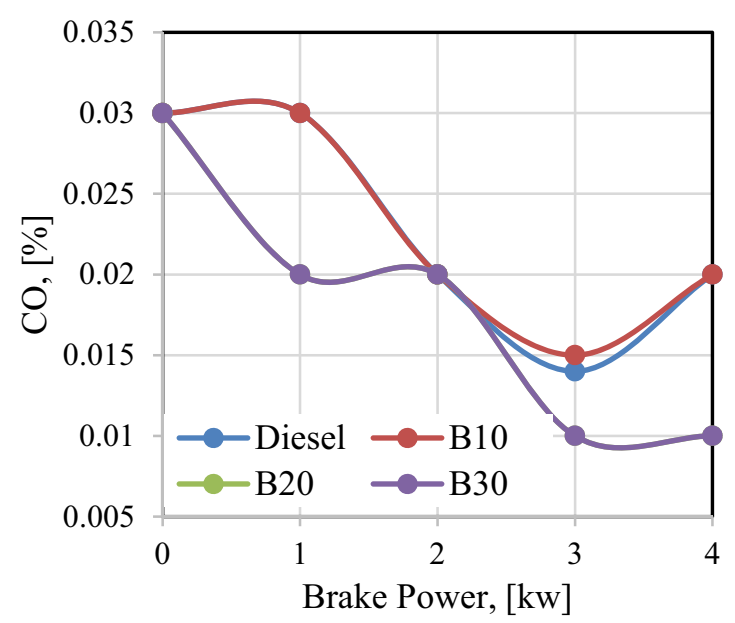

(b)

Fig. 11 Variation of CO with BP. a Jatropha and b Argemone Mexicana

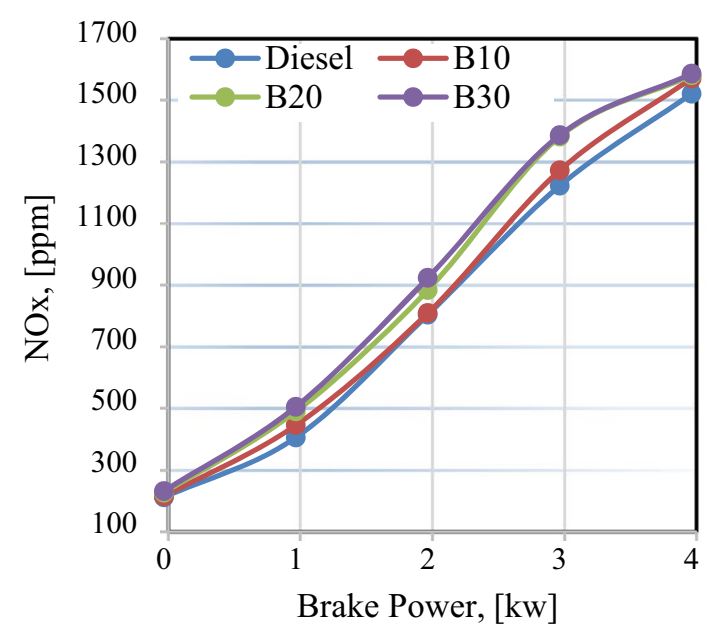

(a)

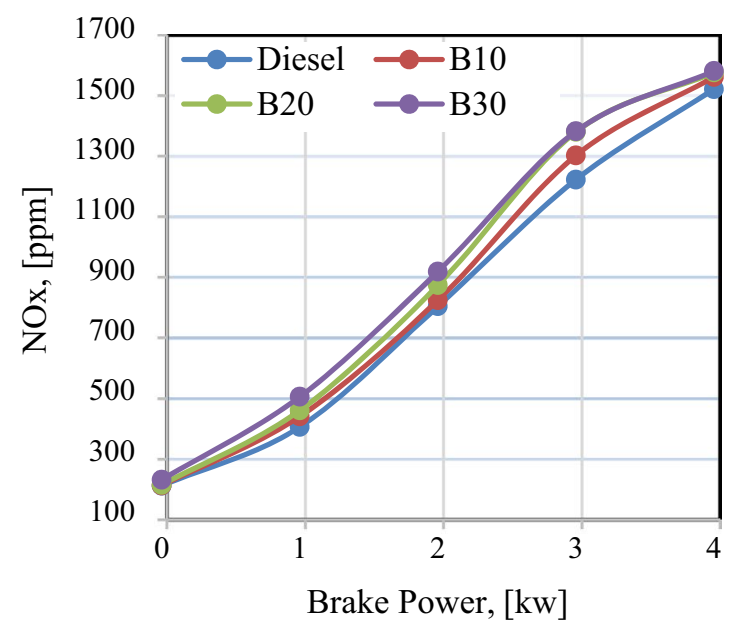

(b)

Fig. 12 Variation of NOx with brake power. a Jatropha and $\mathbf{b}$ Argemone Mexicana

One of the main factors that accelerate the conversion of ester to methyl/ethyl ester is temperature. In this study, four different reaction temperatures have considered to evaluate effect on biodiesel yield while the other factors kept constant. Figure 13 shows the percentage of biodiesel yield at these temperatures. The suitable temperature for higher yield of biodiesel has observed at $55^{\circ} \mathrm{C}$. This result is similar to the results of Bala [22]. Another important factor that affects the yield of biodiesel is the methanol to oil molar ratio. Four molar ratios have considered studying their effect on yield of FAME, 4:1, 6:1, 7:1 and 8:1, while other factors kept constant. The optimal yield has found when the ratio is 6:1. However, molar ratio of greater and

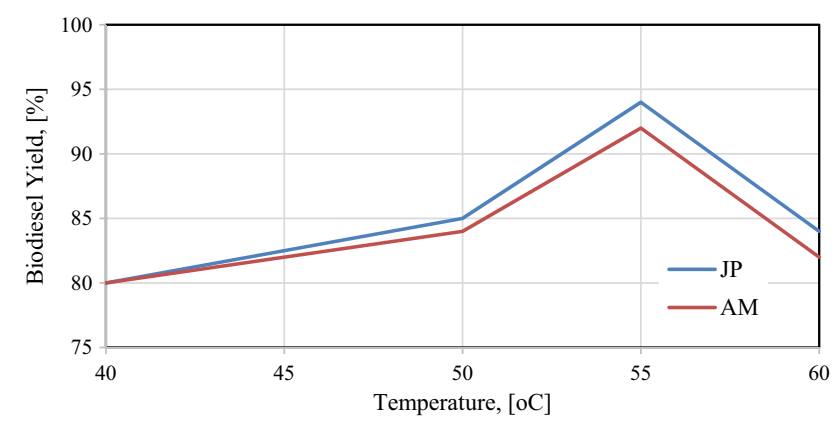

Fig. 13 Effect of temperature on biodiesel yield from Jatropha and Argemone Mexicana 


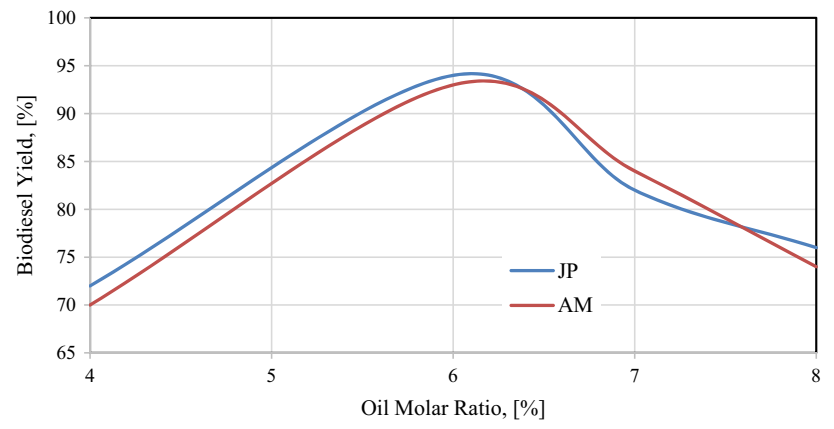

Fig. 14 Effect of methanol to oil ratio on biodiesel yield from Jatropha and Argemone Mexicana

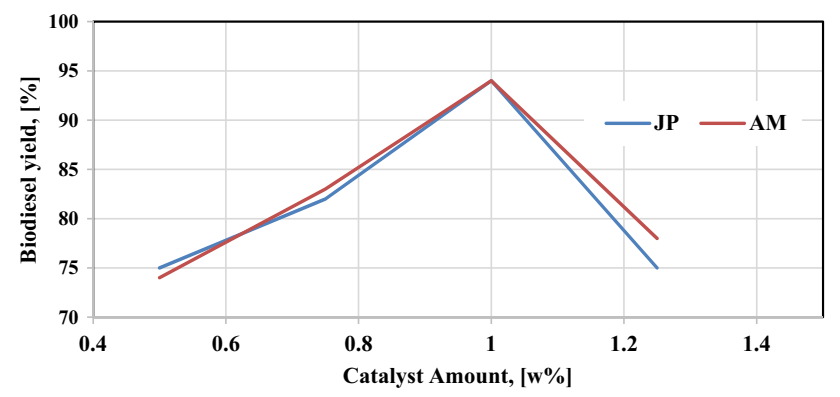

Fig. 15 Effect of Catalyst amount on biodiesel yield from Jatropha and Argemone Mexicana

lower than 6:1 produces lower yield. The maximum yield of FAME using this ratio is $94 \%$ as shown in Fig. 14.

The amount of catalyst is another factor that affects the yield of fatty acid methyl ester. In this research the catalyst concentration of $0.5-1.5 \%$ by weight has used while the other factors kept constant. The FAME has found $94 \%$ yield at a catalyst ratio of $1 \%$ as shown in Fig. 15. Lower and higher catalyst from this value resulted lower yield. This is due to in complete reaction at lower catalyst amount and formation of saponification at higher catalyst values. Similarly, the effect of time on the transesterification reaction has examined by keeping $55^{\circ} \mathrm{C}$ reaction temperatures, 6:1 methanol to oil molar ratio of, catalyst amount of $1 \%$ and agitation speed of $600 \mathrm{rpm}$. Figure 16 shows that the reaction starts very slow due to the heterogeneous nature of the mixture but the yield of FAME increases very fast in the reaction time of $0.5-1 \mathrm{~h}$. On the other hand, the yield of biodiesel starts to decrease after an hour reaction that is the reverse behavior of transesterification process, which decreased output by forming soaps.

The effect of agitation speed has studied under constant parameters of reaction temperature of $55^{\circ} \mathrm{C}$, reaction time of $1 \mathrm{~h}$, methanol to oil molar ratio of $6: 1$ and catalyst amount of $1 \%$. The agitation speeds have set by the behavior of their effect on turbulence behavior. In this regard,

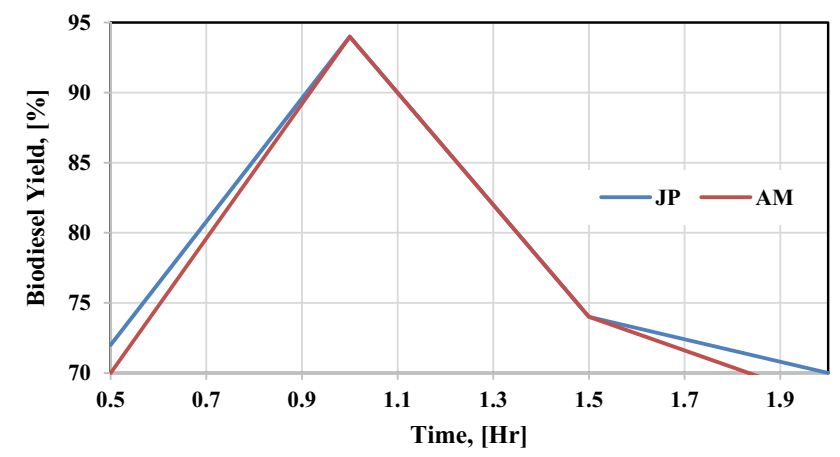

Fig. 16 Effect of reaction time on biodiesel yield from Jatropha and Argemone Mexicana

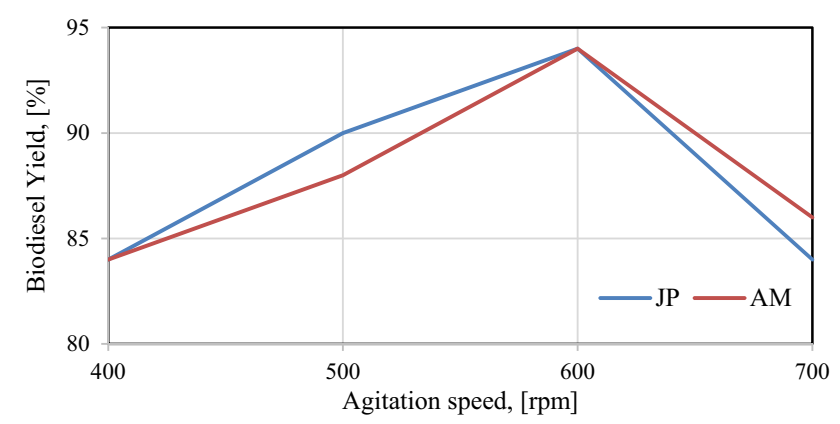

Fig. 17 Effect of agitation speed on biodiesel yield

400, 500, 600 and 700 rpms have considered. Figure 17 has shown the mixing intensity has significantly affected the reaction process with optimal speed to lay within turbulent flow range. Above turbulent flow, it is difficult for the molecules to touch each other. The optimum agitation speed has found at a speed of 600rpm biodiesel yield of $96.5 \%$ and starts to decline if the agitation speed exceeds 600.

The physicochemical property of the produced biodiesel has verified in the laboratory of Ethiopian petroleum supply enterprise. The properties have given in Table 5. The EPE laboratory has confirmed the two biodiesels have met the ASTM D6751-02 standard for biodiesel specification. The viscosity of the biodiesels have found within the standard specification of the ASTM. The density of the two samples were determined at two different temperatures and the result in Table 5 shows that the samples of biodiesel from Argemone Mexicana and Jatropha were found 0.902 and 0.904 respectively this result shows it is a bit out of the ASTM standard. The reason for the increase in density of the biodiesel was incomplete washing which contains impurities of the chemicals used in the production process. But, the gained result was in the range of the ASTM D4052/1298 standards. Likewise, the kinematic viscosity of the biodiesel produced from 
Table 5 Standard properties of biodiesel, diesel fuel and produced sample biodiesels

\begin{tabular}{|c|c|c|c|c|c|}
\hline \multirow[t]{2}{*}{ Property } & \multirow{2}{*}{$\begin{array}{l}\text { ASTM Test method } \\
\text { D6751 }\end{array}$} & \multirow[t]{2}{*}{ Limits $6751-07 b$} & \multirow{2}{*}{$\begin{array}{l}\text { Standard specification of } \\
\text { diesel fuel }\end{array}$} & \multicolumn{2}{|c|}{ Test Results } \\
\hline & & & & AS1 & JS1 \\
\hline Density@ $15^{\circ} \mathrm{C} \mathrm{g} / \mathrm{ml}$ & D4052 & - & 0.9 & 0.862 & 0.874 \\
\hline Calorific value Kcal/kg & - & - & 10,170 & 9753 & 9740 \\
\hline Flash point (PMCC) ${ }^{\circ} \mathrm{C}$ & D93 & Min. 93 & 50 & 176 & 186 \\
\hline Copper strip corrosion $3 \mathrm{~h} @ 100^{\circ} \mathrm{C}$ & D130 & Max. no. 3 & - & $1 \mathrm{~b}$ & $1 b$ \\
\hline Cloud point ${ }^{\circ} \mathrm{C}$ & D2500 & Max. 3 & - & +4 & +4 \\
\hline Kinematic viscosity @ $40^{\circ} \mathrm{C} \mathrm{mm} / \mathrm{s}$ & D445 & $\begin{array}{l}\text { Min. } 1.9 \\
\text { Max. } 6\end{array}$ & & 4.13 & 6 \\
\hline Carbon residue on $100 \%$ of sample & D189 & Max. 0.05 & $\leq 0.15$ & 0.06 & 0.05 \\
\hline Water and sediment (\%V) & D2709 & Max. 0.05 & - & 0.04 & 0.03 \\
\hline Total acidity (mg KOH/g) & D974 & 0.5 & - & 0.71 & 0.163 \\
\hline Ash content (mass\%) & D482 & Max. 0.01 & - & 0.01 & 0.01 \\
\hline Cetane number & D613 & $\geq 47$ & $45-55$ & 80.842 & 92.381 \\
\hline
\end{tabular}

Argemone Mexicana and Jatropha oils were found 4.7 and $5.5 \mathrm{~mm} 2 / \mathrm{s}$ respectively. Consequently, the process of transesterification using methanol reduces the kinematic viscosity of the two crude oils significantly and keeps the results of the kinematic viscosity within the range of the ASTM D445 specification i.e. $\left(1.6-9 \mathrm{~mm}^{2} / \mathrm{s}\right)$. Attaining the value of kinematic viscosity within the range of the standard of ASTM can guarantee the biodiesel as a substitute for conventional fuel.

Flashpoint is one of the most important characteristics of any fuel in which the minimum temperature a fuel can vaporize. The results of the two-biodiesel samples of Argemone Mexicana and Jatropha have found to be $130{ }^{\circ} \mathrm{C}$ and $135^{\circ} \mathrm{C}$ respectively. This shows that the un- reacted methanol has a very great significant role in the reduction of the flash point of the produced biodiesel. Washing of the produced oil and drying to remove the remaining water has a significant effect on the quality of biodiesel. The flash point standard has measured in reference to ASTM D93. Cetane number is another important characteristic that determines the quality of fuel combustion in diesel compression. The problems associated with poor ignition, cold starting, low engine performance, engine combustion roughness and warm up are associated with cetane number. The cetane number of the biodiesels have found as 85 and 91 which is in the range of ASTM D613 i.e. $(\geq 47)$.

\section{Conclusion}

The performance of the $20 \mathrm{~L}$ biodiesel reactor has evaluated by using esterified blends of Jatropha and Argemone Mexicana oils and the average biodiesel yield achieved has achieved $94 \%$ from both inputs. Moreover, the effect of different parameters oil to molar ratio, temperature, agitation speed, catalyst amount and time were evaluated. Specification of the produced biodiesel using this reactor was met the ASTM standards of biodiesel. In addition, the performance of a compression ignition diesel engine fueled by the blends of Jatropha and Argemone Mexicana biodiesel B10, B20 and B30 in comparison to diesel fuel has investigated and found a promising result. Moreover, the emission of biodiesel shows a difference with diesel fuel. On the other hand, it has observed that there is some power loss during testing the engine performance accordingly high fuel consumption has incurred with increased blends of biodiesel. The overall result of the study has shown extraction of biodiesel with locally developed reactor has the potential to revolutionize biodiesel production and address the global and local challenges of fossil diesel.

Acknowledgements The Authors would like extend their heartfelt gratitude to EnPe I project for sponsoring this study as a master thesis and Mekelle University School of Mechanical and Industrial Engineering for its unlimited provision of access to the lab.

\section{Compliance with ethical standards}

Conflict of interest The authors declare that they have no competing interests.

\section{References}

1. Guo M, Meng J (2019) Exploring the driving factors of carbon dioxide emission from transport sector in Beijing-Tianjin-Hebei region. J Clean Prod 226:692-705

2. Chen $\mathrm{R}$ et al (2018) Life cycle energy and greenhouse gas emission effects of biodiesel in the United States with induced land use change impacts. Bioresour Technol 251:249-258

3. Jhessic et al (2019) Biodiesel from waste frying oils: methods of production and purification. Energy Convers Manag 184(15):205-218 
4. Mohammad et al (2019) The potential of utilizing papaya seed oil and stone fruit kernel oil as non-edible feedstock for biodiesel production in Australia-a review. Energy Reports 5:280-297

5. Singh D, Singh SP (2010) Biodiesel production through the use of different sources and characterization of oils and their esters as the substitute of diesel. Renew Sustain Energy Rev 14(1):200-216

6. Stamenković OS, Veličković AV, Veljković VB (2011) The production of biodiesel from vegetable oils by ethanolysis: current state and perspectives. Fuel 90:3141-3155. https://doi. org/10.1016/j.fuel.2011.06.049

7. Singh D, Singh SP (2010) Low cost production of ester from nonedible-oil of Argemone Mexicana. Biomass Bioenerg 34:545549. https://doi.org/10.1016/j.biombioe.2009.12.021

8. Hilditch TP, Williams PN (1964) The chemical constituents of natural fats, 4th edn. Chapman and Hall, London

9. Dorado MP, Ballesteros E, Almeida JA, Schellert C, Lohrlein HP, Krause R (2002) An alkali-catalyzed transesterification process for high free fatty acid waste oils. Trans ASAE. 45(3):525-529

10. Williams P, Mulcahy F, Ford JT, Oliphant J, Caldwell J, Soriano D (2007) Biodiesel preparation via acid catalysis and characterization. J Undergrad Chem Res 6(2):87-96

11. Hanumantha Rao YV, Voleti Ram Sudheer, Hariharan VS, Nageswara Redd P (2009) Use of jatropha oil methyl ester and blends as an alternative fuel in diesel engine. J Braz Soc Mech Sci Eng 31(3):253

12. Elango T, Senthilkumar T (2011) Performance and emission characterstics of compression ignition engine fuelled with non ediable vegetable oil and diesel blends. J Eng Sci Technol 6(2):240-250
13. Demirbas A (2002) Biodiesel from vegetable oils via transesterification in supercritical methanol. Convers Mgmt 43:2349-2356

14. Daniyan IA (2010) Design of small scale biodiesel processor. J Emerg Trends Eng Appl Sci 4(4):576-580

15. Dang et al (2017) Recent insights into continuous-flow biodiesel production via catalytic and non-catalytic transesterification processes. Appl Energy 185(1):376-409

16. Bello El, Ogedngbe IT (2013) Development of a biodiesel processor. J Eng Appl Sci 2(3):182-186

17. Rao RY, Kondhare DD, Reddy NJ (2012) Biodiesel production from argemone mexicana seed oil using crystalline manganese carbonate. J Chem Technol 14(1):65-70

18. National Biodiesel Board, USA (2015) Chapter 32-Fuel quality policy, bioenergy, biomass to biofuels. pp 541-542

19. National Bank of Ethiopia, 2017/18 Annual report

20. Heller J (1996). Physic Nut, Jatropha curcas L. In: Promoting the conservation and use of underutilized and neglected crops. International Plant Genetic Resources Institute, Rome

21. Meher LC, Sagar DV, Naik SN (2006) Technical aspects of biodiesel production by transesterification-a review. Renew Sustain Energy Rev 10:248-268

22. Bala BK (2005) Studies on biodiesels from transformation of vegetable oils for diesel engines. Energy Educ SciT echnol 15:1-43

Publisher's Note Springer Nature remains neutral with regard to jurisdictional claims in published maps and institutional affiliations. 